\title{
SYSTEMATIC TRANSFORMATION REFORMS IN UZBEKISTAN AND ECONOMIC
}

\section{Bakhtior Islamov}

\section{Approach of Uzbekistan to Systematic Transformation}

From the first day of Independence Uzbek people and its government looked for the model of gradual transition to socially-oriented market economy with a strong democratic state and open peaceful policy.

Taking into account the experience of other nations and on the basis of thorough analysis of the peculiarities of its social, economic and human development, with specific historical background, Uzbekistan has chosen its own approach to a systematic transformation.

The five principles of its strategy were formulated by President Islam Karimov very soon after independence were as follows:

1. The State is the main power driving economic and political reforms;

2. Economics takes priority over politics, with de-decolonization of both domestic and foreign economic relations;

3. Rule of law and order based on a new legal framework;

4. Social protection, especially the most vulnerable groups of people;

5. Step-by-step approach to systematic transformation. ${ }^{1}$

The state was not only proclaimed, but has become within this period the main power behind political and economic reforms on the basis of gradualist approach and strategy of transition to the socially oriented market economy. The common sense of the people of Uzbekistan could be expressed as "do not destroy the old house before building a new one", and they generally supported such strategy.

Within all period of independent development special emphasis was made on the principles of gradualism and social protection of the population. Fulfillment of these principles provided economic, social and political stability.

\section{Real Economy and Sect oral Reforms}

Another peculiarly of systematic transformation in the republic is that real sectors of the economy have been chosen by the state and people of Uzbekistan as a top priority.

Crucial changes have been introduced into agriculture and industry, and this shifted the economy towards a more industrialized and self-sufficient struc- 
ture on the basis of an import substitution policy. Decline in Real GDP of Uzbekistan according to Statistical Committee of CIS of about $16.7 \%$ within 1991-1994 had been the lowest in comparisons with all other post-Soviet Republics, (for instance, in Azerbaijan decline was by 53.8\%, Armenia-60.9, Belarus36.3, Georgia-79.8, Kazakhstan-50.1, Kyrgyzstan-50.0, Moldova-61.2, Russia-42.2, Tajikistan-67.0, Ukraine-47.0\%)

\subsection{Reforms in Agriculture}

From the beginning agriculture was considered as a key sector in the economic transformation of Uzbekistan.

More than two thirds of population lives in rural areas and occupies in the production directly or indirectly connected with agriculture. More than one third of the gross national product comes from agricultural output.

Strategic goals to abolish cotton monoculture and achieve food self-sufficiency, especially grain independence were put into the agenda from the first days of reforms.

The share of irrigated land devoted to the grain production increased from $29 \%$ in 1992 to $40 \%$ in 1995, and in 1995 grain production in the Republic covered $73 \%$ of domestic consumption (in comparisons with $15 \%$ in 1991). ${ }^{2}$ In 19953.2 man, tons of grain were produced, almost two and half times more than in 1991. The government and people of Uzbekistan are trying to achieve self-sufficiency as soon as possible. Other targets are increased production of potatoes using new technology from Netherlands, as well as raw materials for sugar production.

Cotton production stabilized at the level of $4 \mathrm{men}$. Tons despite a decrease in arable land under cultivation. All state farms and agricultural enterprises which were notoriously known for their inefficiency have been privatized or transformed into different collective or leased enterprises. The plan is to give more flexibility and incentives to fanners to increase production of meat, milk, fruits, vegetables and other food products. Only for cotton and grain state orders have been kept but gradually reduced with increased procurement prices.

Within period of 1992-1995, on the basis of 1,066 state farms, 530 collective farms, around 350 cooperatives and over 100 leased farms and farms of other types of ownership were established. In addition 1,516 cattle-breeding farms were converted into working collectives.

As a result, in 1995 the. None'-governmental sector produced $98 \%$ of agricultural output of Uzbekistan.

According to the Constitution and Law on Land the sown land can not be sold as private property but can be converted to a long-term lease with the right to inherit it. 
The population has been endowed with land through the expansion of their plots and the allotment of new ones. Over 218,000 additional hectares of irrigated lands have been allocated for the private use of citizens. The total area of land in such plots reached almost 602,000 hectares.

Over 9 million people enjoy the benefits of this system. The average area of these plots is more than 0.2 hectares, an amount of considerable value under conditions of limited land resources.

These plots of land privately, i.e. used more efficiently, provided more than three-fold increase of food (grain, potato and other vegetables) production, as well as opened possibilities for breeding of $74 \%$ of the cows and $50 \%$ of the sheep and goats of the republic. Due to private farmers, production of meat increased three-fold, of milk-doubled, of eggs increased for 1.5 times.

\subsection{Industrial development}

Uzbekistan is the only Republic of CIS which succeeded by mid-1996 in achieving positive growth in comparison with 1990. According to data given by "Independent Newspaper" based in Moscow, by July 1, 1996 industrial production of Uzbekistan has overcome the level of 1990 and consisted of $106 \%$, while in Russia it was 47\%, in Turkmenistan-81, Belorus-63, Ukraine-55, Armenia and Kazakhstan-48, Moldova-43, Azerbaijan-41, Kyrgyzstan-38, Georjia-18\%. ${ }^{3}$

This achievement of industrial policy goals was combined with structural changes based on import substitution in fuel sector and development of new facilities for machine building.

Within short period of time, Uzbekistan became self-sufficient in oil. In 1991-1994 the production of oil in Uzbekistan increased almost two times, at the same time in all oil-producing post Soviet republics it decreased: in Russia for $31.7 \%$, Kazakhstan-25.9\%, Turkmenistan-24.1\%, Ukraine-14.3\%. Production of natural gas increased from 42 bins. To 50 bin. Cubic meters, i.e. growth was $57.8 \%$ while it decreased in Kazakhstan for-43.2, Ukraine-25.0, Russia-4.1\%. ${ }^{4}$

Uzbekistan is the only republic in the FSU which has managed to achieve growth of oil and gas production. Now, it has become the second largest producer of the gas after Russia, and the third largest oil producer after Russia and Kazakhstan. It is also worth noting that increases in production were so far connected with mainly domestic investments.

In terms of its natural resources, Uzbekistan is one of the world's ten richest countries. The estimated value of these resources is $\$ 3$ trillion, of which $\$ 6$ billion is extracted annually. In fact, $95 \%$ of all minerals known to man are 
found in the republic. It has the fourth largest deposits of gold of any country on earth, and the seventh largest uranium deposits, more than 900 minerals and 300 metals. ${ }^{5}$ According to the World Bank estimates, it produces about 70 tones of gold a year and by year 2000 the target is to increase the production of gold for two times. Thirty gold mines have been discovered in Uzbekistan of which. Ten are now operating. Modern technology is imported together with formation of joint ventures with foreign partners. In addition, the Uzbek-American "Zarafshan-Newmont" Joint Venture, with \$225 man. Capital raised within eighteen months, started in 1993 to process, the waste from traditional mining into gold. ${ }^{6}$

The republic also produces copper, Zink, silver and such rare metals like molybdenum, indium, palladium and other metals; with $15-20 \%$ of copper isprocessed into cables and the rest is exported.

Uzbekistan started to develop its own iron ore mine which requires big investments. Meanwhile, it is net importer of almost all iron and steel, mainly from CIS countries.

The state is paying big attention not only to developing primary but manufacturing industries as well.

Output of the machinery industry increased to more than $1 / 5$ in one year (1995). To traditional production of agricultural machines, aircrafts and electrical equipment in 1996 was added trucks produced with Mercedes-Benz and cars and electronics with Daewoo. Foreign investors entering this sector with modern technology and equipment are highly encouraged by the government.

Light industry of Uzbekistan represented by 118 companies, had a more smooth transition to market environment than many other sectors of the economy. Their association "Uzbeklegprom" is the only member of the International Federation of textiles from the CIS.

The share of cotton processed domestically almost doubled within first four years after independence, and was $15 \%$ in 1995 . The target aimed at by the government to increase this share up to $30 \%$ in the nearest future and establish a textile center in Uzbekistan. Joint ventures with foreign companies has already started production of 400 new high quality goods especially in such fields like cotton, silk, wool, leather manufacturing, as well as fruits and vegetables processing.

Foreign capital entered also into production of chemical, pulp and construction materials. 


\subsection{Infrastructure}

Telecommunications was one of the least developed sectors of infrastructure with old-fashioned equipment, inherited from FSU. Before independence, Uzbekistan had only thirteen lines for international calls and all of them passed through Moscow. Now within five years the republic possesses 150 lines for international calls and direct connections with six European countries and Japan.

In August 1995, the government adopted a programmed by whom $25 \%$ of all telephone numbers will be digitalized by 1997, rural telephonization is to be improved and a trans-Eurasian fiber optic network developed. Joint ventures with British, German, Italian companies have been established with the aim of investing in this sphere, to modernize it as soon as possible.

Uzbekistan has a rather well-developed domestic transportation system, including railroads, auto transport, airways and pipelines. However, the nearest port is about 2,000 km away and all traditional export routes depend on transit via Russia.

Uzbekistan has the most extensive rail network in the region with $6,700 \mathrm{~km}$ of railroads. A five-year programmed has been introduced by the government for constructing 2 new domestic railroads, electrifying $400 \mathrm{~km}$ additionally to the existing $60 \%$ of total railroad system which has been operating already on electricity. This shows the government's intention to provide all necessary infrastructural support for investors.

Uzbekistan has also rather developed road system with total length of $50,000 \mathrm{~km}, 90 \%$ of which is paved. Today, $95 \%$ of all export-import goods are delivered to and from Uzbekistan by road. "Central Asia Trans" has become the main international haulage agent and it handles all international trade. It is the second largest company of this kind in CIS after Russia's "Sovavtotrans". 70\% of all deliveries of the company go to Europe.

"Central Asia Trans" is a state association which includes several plants and facilities under its auspices, has also developed very active commercial activities showing that state-owned enterprises could be also efficient under market environment.

Uzbekistan pays special attention to Uzbek Airways, which derives today $30 \%$ of its revenues from cargo freight. The company offers direct flights to London, Frankfurt, New Delhi, Karachi, Kuala Lumpur, Bangkok, Seoul* Peking, Tel-Aviv, Djidda, a total of more than 20 foreign cities. All regional centers in the republic have airports. Uzbekistan has an agreement with the German govern- 
ment to improve Tashkent's international airport, and another with the Japanese to upgrade the airports in Bukhara, Samarkand and Khiva. Economic and feasibility studies are currently being prepared. While a new type of domesticallyproduced airplanes is being introduced for domestic flights, for international flights, Western equipment and airplanes, such as Boeings aircraft, will continue to be imported.

Uzbekistan's electric power sector produces half of, all electricity generated in Central Asia. Per capita consumption in the Republic is as high as in Italy or Spain. Even with this high capacity a new power station paid for by the state is under construction to meet future needs of domestic industry and to increase export to neighboring countries.

\subsection{Foreign Economic Activities}

Sharp disruption of inter-republic trade ties within FSU and CMEA led to decrease in foreign trade. This reduction took place mainly at the expense of CIS. The main reasons for that were: (1) a general decline of output and aggregate demand in all post-Soviet states; (2) a transition from distorted and inefficient structure of intra-Union economic relations to the new structure of mutually advantageous exchange of commodities and services; and (3) new direct horizontal links between enterprises that not been properly established and worsened situation because of a non-payment problem.

Uzbekistan, more than other republics, has been able to offset to certain extent these difficulties as it managed to provide proper institutional changes, find new markets for its exports and imports by organizing within a short period of time import substitution production.

Collapse of the administrative-command system with its state monopoly on foreign trade and extreme centralization of it, required creation of various institutions such as the Ministry for Foreign Economic Relations, the National Bank for Foreign Economic Activity and Customs Administration have been formed almost from zero. Administrative constraints were decreasing on the basis of gradual approach to trade liberalization.

Until the end of 1994, the Ministry of Foreign Economic Relations was responsible for centralized exports and imports and implementation of state policy in this sphere through a license system. In 1994-1995, decrees were issued decreasing number of goods from 176 to 4 items (cotton, oil, ferrous and non-ferrous metals) subject to export licensing, and only antiques, agricultural and meat products (grains, bread, flour, sugar, tea, meat and poultry) subject to export bans. 
Since early 1992, Uzbekistan has signed economic cooperation, double taxation and tax evasion treaties with more than twenty countries. It was granted trade benefits by the U.S. in August 1994, under the General System of Preferences (GSP). In 1991-1994, Uzbekistan had bilateral barter type trade agreements with several CIS countries. As for end 1995, about US\$ 190 man. Were owed to Uzbekistan under these agreements. The republic recently has started to practice new type of agreements, eliminating barter trade between governments and allowing for direct contracts between entities and / or individuals.

With the reduction in the number of licensed goods Ministry of Foreign Economic Relations became more oriented to the development of trade strategies and the trade regime for Uzbekistan, drafting trade regulations, monitoring export prices and coordinating work with international organizations.

In April 1994, the government started to use the Republican Foreign Currency Exchange, in which Central Bank of Uzbekistan and eighteen commercial banks conducting regularly interbrain auctions. The total volume of foreign currency sales exceeded US\$ 1.3 billion in 1995, which is eleven times higher than that in 1994. For the first nine months of 1996, foreign currency sales totaled LJS\$ 2.3 billion. $^{?}$

The National Bank for Foreign Economic Activity of the Republic, which was founded five years ago, is responsible for the development of export oriented industries, attraction of foreign investments, organization of international settlements, management of state currency assets, banking services. Starting from 1993, according to "The Banker" journal rating, it has entered the first thousand of biggest banking institutions of the world. For the second year, the National Bank keeps the first position among fifty leading world's banks with BIS (Bank of International Settlements) ratio equal to $106.95 \%$ and twenty second place by the index of profitability on assets. Today the ${ }^{\wedge}$ ownership capital of the bank has reached US\$ 340 man., and the amount of its assets exceeds US\$ 3 bin...

The National Bank for Foreign Economic Activity of Uzbekistan serves credit lines, opened by EXIM banks of Japan, the U.S., Turkey, Korea, such international financial institutions like IFC, EBRD, ADB, export insurance agencies as Hermes (Germany), Kolas (France), ECGD (Great Britain), Sachem (Italy), ERG (Switzerland), Du Krua (Belgium), banks including Chase Manhattan, JP Morgan, Bank of America, Deutsche Bank, Tokyo-Mitsubishi bank, Sakura Bank. In the frame of these credit lines, the National Bank serves 49 projects for the total amount of US\$ 1.9 bin... 
Concurrently, Uzbekistan and Japan are strengthening their cooperation and considering several joint projects including: - development of Kokdumalak oil-gas condensate deposit;

- Construction of oil-processing plant in Bukhara;

- Development of Kyzylalmasay gold deposit;

- Reconstruction of Almalyk metal-mining plant;

- Cooperation on establishment of joint ventures in the textile industry.

Such Japanese companies, as Mitsui, Mitsubishi, Marubeni, NICO Iwai, Tomen, Toho Rauon and such banking institutions as EXIM Bank, Sakura Bank, Bank of Tokyo Mitsubishi, Fuji Bank, and investment companies such as Nomura Securities, Overseas Economic Cooperation Fund and others are also becoming well-known in Uzbekistan.

The total volume of approved Japanese investments to the economy of the Republic today exceeds US\$ $310 \mathrm{mln}$... New projects on joint financing for. The total amount of more than US\$ $800 \mathrm{mln}$. Are under consideration.

Japan is also rendering technical assistance to Uzbekistan. For instance, in 1993 Japanese Government accorded US\$ limn. Grant for development of Uzbekistan's telecommunications strategy. Recently, Mitsui received orders with total worth of 16 billion Japanese Yen to install 360,000 telephone circuits in Uzbekistan. The deal is one of the biggest contracts awarded to Japanese companies for telecommunications projects in Central Asia. Exchange and other related equipment will be built over next three .years, 250,000 circuits is to be bunt in four north western regions of Uzbekistan with 10 " billion Japanese Yen financing to be provided by the Japanese government. ${ }^{8}$

The energetic promotion of Uzbekistan by the government through various activities has greatly increased international confidence in the country. There is an ongoing trend to restore relations with traditional trading partners while, increasing trade with new ones.

Foreign trade after independence has become very important to Uzbekistan; its turnover was 86\% of GDP in 1994 and 60\% in 1995.

In 1991-1995 Uzbekistan achieved radical changes in its foreign trade. Uzbekistan had a trade surplus US\$237.3 mln. In 1994 and $319.3 \mathrm{mln}$. In 1995. These were equivalents of $3.6 \%$ and $2 \%$ of GDP respectively. In 1995, there was significant shift away from Post-Soviet traditional partners to the West. The share of these countries of total foreign trade decreased from more than $55 \%$ in 1993 and 1994 to about 40\% in 1995. Imports of oil and gas condensate decreased in one year from $40 \%$ in 1994 of total to $3 \%$ in 1995 . Import of grain also 
decreased five times from $5 \mathrm{mln}$. Tones in 1991 to 1 more. Tones in 1995. This reflected increased domestic production of oil and grain, more efficient use of available supplies. At the same, there was tangible rise in imports of products in metallurgy, machine building, chemical and petroleum industries, witnessing about the increase of investment in Uzbekistan. In 1995, imports of these goods were more than $50 \%$ of total imports from traditional partners relative to $17 \%$ in 1994. ${ }^{9}$ However, more than a 20 -fold increase of the transportation services (because of increase of transit tariffs through CIS countries) offsite it to major extent. To overcome dependence on traditional transportation routes and diminish negative effects of its location as a double landlocked nation, Uzbekistan is considering a number of alternative projects with neighboring countries.

Imports of machinery, raw material and consumer goods from non-traditional partners more than doubled in 1995, while imports of food declined. Uzbekistan had trade surplus both with traditional and nontraditional countries in 1994 and 1995.

Hi terms of composition of exports, raw materials and processed industrial products (including cotton fiber, gold) constituted better half of total exports. Most of exports were channeled through state-owned export companies regulated by the Ministry of Foreign Economic Relations.

\section{1nvestment}

Among all other post-Soviet Republics, Uzbekistan became the only exception over the volume and structure of capital investments.

- In 1995, 70\% of capital investments were directed towards industrial construction, $10 \%$ more than in 1994 .

- The share of funds allocated to the purchase of equipment, technologies and production lines grow from 19 to $32 \%$.

- Nearly half of the capital invested, $43 \%$ was directed to the non-governmental sector. This is by $17 \%$ more than in 1994 .

- More than half of the non-governmental funds, or $22 \%$ overall investment, was allocated to joint ventures.

- In 1995 the share of foreign investment in the total volume of capital/ investment grew from 0.6 to $14.3 \%$.

Foreign direct investment and foreign assistance was targeted at fuel and energy, light industry (tobacco, textile), metallurgy (fore mostly gold production) and machinery (automobiles and electronics).

As a result, the investment-GDP ratio rose from $26 \%$ in 1994 to $33 \%$ in 1995. Most of the increase in investment is estimated to have been financed by 
government and non-government savings. While the contribution of foreign savings was only $0.5 \%$ of GDP in 1995 . Contribution of the Government to the financing of investment in 1995 reflected the tightening of fiscal policy.

Due to Government investment policies, structural reforms in Uzbekistan were based on the development of technologically advanced branches and introduction of import substitution production.

In 1995 the highest rate of development was achieved in chemical and pharmaceutical industry (200.4\%), the automobile ilndustry (153.4\%), instrument manufacturing (126.7\%). 400 new kinds of products were introduced in the republic in 1995 alone.

\section{Macroeconomic Stabilization}

Since 1991, Uzbekistan like every newly independent state has been suffered from macroeconomic shocks connected with disruption of political and economic ties within former Soviet Union and with transition to market based economy.

However, due to its specific characteristics of socio-economic development (structure of its production and trade), as well as properly chosen strategy, the republic has managed to diminish these shocks.

Positive changes in restructuring of the real sectors of economy, promotion of production of tradable goods, combined with policy of import substitution gave tangible results. The external current account deficit in relation to a GDP was reduced from almost $12 \%$ in 1992 to less than $1 \%$ in 1995 . At the same, gross official international reserves rose to the equipment of over 6 months imports by the end of 1995 .

In 1991-1993 the Government tried to diminish impact of decline in outputs via financial subsidization of production and consumption. But inflation accelerated, shortages emerged and there was rapid accumulation of short-term external debt by the end of that period.

Only following the introduction of national currency on the 1 July 1994, it became possible to tighten financial policies. The Central Bank of Uzbekistan raised the interest rate on its rediscount credits and shortened credits to lossmaking state enterprises. The Government started also to establish harder budget constraints to SOEs and reduced other expenditures.

As a result the consolidated fiscal deficit in relation to GDP fell from $18.4 \%$ in 1992 and $12.1 \%$ in 1993 to $3.6 \%$ in 1994 and less than 3\% in 1995.

According to official CIS statistics, in 1995 Uzbekistan's real GDP declined 
by only about $1 \%$ while inflation rates were sharply reduced from $1300 \%$ in 1993 , to $233 \%$ in 1994 and $2 \%$ a month by the end of 1995 .

In 1995-1996 Uzbekistan continued to follow a managed floating exchange rate system. In 1995, exchange rate for the sum, Uzbek national currency, was depreciating against the US dollar by $50 \%$ in real terms. In the first half of 1996 , the nominal rate has remained more or less stable against the US dollar resulting in further appreciation in real terms with this period. However, in the second half of 1996 the gap between official and market exchange rates has been again increasing.

As a result of sharp worsening of international prices for the main exports of Uzbekistan (especially for cotton-fiber and for copper) and continued increase of import capital goods (machines and equipment) connected with program of investments, the external current account deficit is somewhat widened. However, in a whole period after independence beginning with 1991, the results in Uzbekistan, according to competent observers from outside and inside the country, are much more impressive than in any other Post-Soviet Republic within Central Asian Region or CIS ${ }^{10}$

Political and macroeconomic stability established in the republic after independence could permit to continue further structural reforms efforts which would serve as the foundation for economic recovery and improvement in living standards.

Of course, the Government is still considering to target at strengthening the national currency, making it fully convertible, decreasing inflation rate and continuing restructuring the economy with more intensive introduction of market mechanisms.

\section{Initial Results, Problems and Prospects.}

Analysis of economic reforms and private sector development shows that in Uzbekistan within 5.5 years of independence crucial changes were achieved. 1996 took in this respect special place.

(1) The main objective to stop decline in real sector development was reached. The growth in 1996 in comparisons with 1995 was marked by following figures: GDP-101.6\%, industrial output-106\%, production of consumer goods$108 \%$, foreign trade- $140 \%$ (foreign trade with non-traditional partners- $170 \%$ and its share in total was- $72 \%$ ).

(2) A step forward was made in macroeconomic and financial stabilization. Annual inflation rate was 2 times less than in previous year. This trend was a 
result of tightening of fiscal and monetary instruments. Budget deficit was less than $3.5 \%$. The level of cash money emission decreased from $20.4 \%$ to $19.7 \%$. US\$ 3.3 bin. Were sold in the Republic's Currency Exchange which is 3 times more than in 1995.

(3) Level of investment reached 166.5 bins. Sums with $66 \%$ of which was directed into production of top priority goods. Foreign investment with amount of US \$ $825 \mathrm{mln}$. Was two times higher than in 1995. And in only 1996 the economy of Uzbekistan hosted more FDI than in all previous 4 years after independence. 150 new kinds of commodities were produced in the republic for the first time in the history of Uzbekistan, including 3 types of automobiles.

(4) As a result of desalination and privatization $68.9 \%$ of national income, $53.4 \%$ of industrial and more than $98 \%$ of agricultural outputs was produced by non-state sector of Uzbek economy. This sector employed in $199670 \%$ of all workers of Uzbekistan. More -than 1/3 of all private and small enterprises. (34,500 out of total around 100,000) were formed in only one Xear-1996.

(5) Turnover of shares of privatized enterprises reached in 19968.3 bin sums, which was 4.8 times more than in 1995. Secondary security markets also increased and its share was $30 \%$ of a total amount of securities sold in 1996.

(5) Turnover of shares of privatized enterprises reached in 19968.3 bin sums, which was 4.8 times more than in 1995 . Secondary security markets also increased and its share was 30\% of a total amount of securities sold in 1996.

Single and unified security markets infrastructures has been formed on the basis of "Tashkent" National Stocks Exchange, National Depository "Vakit", "Cons audit-Inform" agency, and their 12 branches and 375 investment institutions.

(6) Entrepreneurship development was supported by state (legally, financially, by tax incentives) in addition credit lines by international financial institutions (IFC, EBRD, ADB), as well as foreign ODA institutions (OECF, EximbankJapan, KfW-Germany, Central-Asian American Foundation-the U.S.) were opened with total amount about US\$ $350 \mathrm{mln}$.

At the same time there were unresolved problems in economic transformation, structural adjustments and changes in the thinking and training of people under new environment.

(1) Despite decrease of inflation, there is a lot to do to achieve real macroeconomic stabilization and improvement of financial situation of enterprises and the whole sectors of production. Lack of turnover capital, bad debts and related payment problems are still acute. 
(2) Institutional changes, creation of new infrastructures have not lead to crucial changes in the efficiency of production, to tangible increase in labor productivity and profitability of enterprises based on different types of property.

(3) the most difficult area was agriculture. Reforms wert slow and mainly formal. As a result of lack of real transformation agricultural production with actual incentives to farmers

As unfavorable weather conditions in 1996 for cotton, the main objectives put into prognosis were not fully fulfilled.

(4) Creation of market infrastructures, cofporatization and privatization processes have not yet led to real structural changes in the economy, especially in bringing investment into manufacturing and export-oriented productions.

(5) There are still big obstacles for real development of entrepreneurship and private initiative. Stereotypes of administrative-command system are still predefined of behavior of lower-and mid-level bureaucrats and managers.

Legal institutions (courts, advocates' offices, etc.) as well as Insurance and audit systems are not protecting properly private businesses neither against violators of law, nor against economic and financial risks.

(6) Mentality of dependents and commanders in chief, lack of sense of ownership, knowledge of market economics and business administration are creating serious brakes for further development of economic reforms and entrepreneurship.

Without resolving these problems properly it is not possible to achieve real improvement in transformation of the society to higher stage of economic and social development. What are main goals targeted by the Government of Uzbekistan at this stage?

Formation of the middle class of owners as main basis for economic reforms through small and medium entrepreneurship, creation of sense of masters of property via distribution of shares of large enterprises among vast population.

- The state and people of Uzbekistan are against of sharp differentiation of population, creation of economic and social short-term tensions and longterm problems. Social orientation of reforms is to be kept.

- Privatization and desalination not formally but in reality are to be pursued to create institution basis for mixed economy with optimal combination of private, collective and state property with a goal to increase efficiency production, standards of living and quality of life. 
Thus, the priority is further to be given to small and medium private entrepreneurship and vast groups of owners-shareholders in the new structures of the society and economy of Uzbekistan to provide properly the needs and interests of the majority of the population.

\section{ENDNOTES}

1. Islam A. Karimov, Uzbekistan: soy put' obnovleniia I progress. Tashkent, 1992, p, 37 for more details on strategy of Uzbek Government also sees, Islam A. Karimov, Uzbekistan pox Puti Uglubleniia Ekonomicheskikh Reform, Tashkent, 1995

2.IMF. Selected Issues and Statistical Appendix. June 10, 1996. Washington, D.C.

3.Nezavisimaya Gazeta, 22 November 1996

4."Ekonomika Strand Sodruzhestva Nezavisimykh Gosudarstv v 1994. Statisticheskly komitet SNG (Kratki spravochnik), Moscow 1995 IntertaxStatisticheskoe obozrenie, 1995 No 5/6 (10 February): 24.

5. See. "Golden Opportunities", by Ben Airs, Moscow 1996, p.20

6. Annual Report of National Bank for Foreign Economic Relations of Uzbekistan, Tashkent 1994, p.3

7. The data here and below is from Reports presented at the Conference by Minister of Finance of Uzbekistan B.Khamidov, Chairman of National Bank for Foreign Economic Activity of Uzbekistan R. Azimov and others at the conference, organized by OECD at Mite House, Tokyo, Japan on December 18, 1996

8. Japan Times, 14 January 1997, p. 10

9. See, Uzbekistan. Informationaniy sonic Gosprognozstat, 1996, pp. 28,43

10. See, Central Asia in Transition: Dilemmas of Political and Economic Development, (edited by Boris Rumer) M.E. Sharpe, Armonk New York, London, p. 118-119 